\title{
Effect of Sowing Dates on Yield and Growth Parameters on Different Wheat (Triticum aestivum L.) Varieties
}

\author{
Shital Bangar ${ }^{1 *}$, Chetana Mandavia ${ }^{1}$, Diksha Tajane ${ }^{2}$ and M. K. Mandavia ${ }^{3}$ \\ ${ }^{1}$ Department of Genetics and Plant Breeding, ${ }^{3}$ Department of Biochemistry, Junagadh \\ Agricultural University, Junagadh 362 001, India \\ ${ }^{1}$ Deparment of Agronomy N. M. college of Agriculture, Navsari Agricultural University, \\ Navsari 396450, India \\ *Corresponding author
}

\begin{abstract}
A B S T R A C T
A field experiment was carried out in Factorial Randomized Block Design (FRBD) with three replications to study the effect of sowing dates on yield and growth parameters on different wheat varieties. Nine different wheat varieties viz., GW 433, GW 431, HI 1571, GW 432, RAJ 3765, HD 2864, HI 1563, HD 3091 and PBW 670 sown in timely and late sown conditions (i.e., 22 November and 6 December 2012) were included in the study. Late sown varieties were exposed to $32.40 \mathrm{C}$ and $33.9-35.30 \mathrm{C}$ temperature during flowering and grain filling period as against $29.40 \mathrm{C}$ and $30.3-33.30 \mathrm{C}$ temperature faced by timely sown wheat. Grain yield was reduced under late sown condition as compared to timely sown wheat. Considering the yield reduction, variety HI 1571 exhibited the least reduction (1.73\%), followed by GW 433(7.90\%) and GW 431 (13.8\%) under late sown condition, whereas variety PBW 670 recorded maximum grain yield reduction $(29.41 \%)$. leaf area index had positive correlation with grain yield but were non-significant. Specific leaf weight had negative and non-significant correlation. The varieties HI 1571, GW 433 and GW 431 could be considered as thermo-tolerant varieties in view of the least reduction in their grain yield under late sown condition. Under late sown condition, variety GW 433 recorded higher AGR and SLW while GW 431 had maximum LAI. RAJ 3765 recorded maximum NAR.
\end{abstract}

\section{Keywords}

Growth parameters, Net assimilation rate, Lear area index, Specific leaf

Article Info

Accepted:

15 February 2020 Available Online: 10 March 2020

\section{Introduction}

Wheat (Triticum aestivum L.) is one of the important cereal food crops of the world and consumed by nearly $35 \%$ of the world population and providing $20 \%$ of the total food calories. Wheat consumption is increasing worldwide as a result of higher income levels, urbanization, and substitution with other cereals. Therefore, the nutritional quality of the wheat whole meal has a significant impact on human health and wellbeing especially in the developing world.

Wheat flour is used for making a large number of products such as chapati, bread, 
biscuit, noodles and pasta. The quality of wheat based foods and the processing of wheat flour dough are strongly related to the composition of proteins and starch. Starch being the major constituent of wheat flour plays an important role as a determinant of food product quality.

Adverse environmental conditions during the anthesis and grain filling period have been identified as a major constraint to wheat quality world-wide $(1,2)$. Growth of kernels is reduced depending upon the degree of stresses and thereby limiting final grain yield (3). The reduction was found to be more severe when the stress occurred suddenly rather than gradually and at early stages of grain filling than at later stages (4).

Extreme temperature during grain filling has been identified as a major source of variation in wheat grain yield and flour quality characteristics (5). Higher temperature enhances leaf senescence causing reduction in green leaf area during reproductive stages. The rapid leaf senescence ultimately resulted in less productive tillers pre plant, which is one of the major causes of yield loss of wheat. However, crop response to high temperature varied with variation of temperature, duration of exposure, crop growth stages and also due to the level of crop tolerance $(6,7)$. In view if the changing climate condition, it is pertinent to analyse different wheat varieties in order to pinpoint the variety which could perform well and tolerate high temperature when sown late.

A number of studies have been undertaken to investigate effect of timely and late sowing on grain yield of high temperature on growth parameters and grain yield.

Therefore, this paper seeks to examine the effect of temperature prevailing under timely and late sowing times on grain yield as well as leaf area index, AGR, RGR and specific leaf weight and to examine the relationship between these growth parameters and grain yield.

\section{Materials and Methods}

The experiment was carried out during Rabi 2012-13 at Instructional Farm Krushigadh, Junagadh Agricultural University, Junagadh, India in Factorial Randomized Block Design (FRBD) with three replications. Nine different wheat varieties GW 433, GW 431, HI 1571, GW 432, RAJ 3765, HD 2864, HI 1563, HD 3091 and PBW 670 were sown in timely and late sown conditions (i.e., 22 November and 6 December 2012). The recommended agronomic practices for fertilizer inter-culturing and irrigation were followed.

Grain yield was recorded from the net plot and was exhibited on the hectare basis. Protein, starch and wet gluten contents of wheat grains were determined by InfratecTM1241 grain analyzer (Foss NIR System INC., Hoganas, Sweden) (8). The statistical analysis of data was carried out by analysis of variance method suggested by Panse and Sukhatme (9).

\section{Results and Discussion}

In wheat, grain filling stage contributes to maximum grain yield (10). In present study, late sown varieties were exposed to $32.40 \mathrm{C}$ and 33.9-35.30C temperature during flowering and grain filling period as against 29.40C and 30.3-33.30C temperature faced by timely sown wheat. Thus, there was increase in 20-3.60C when the crop was planted in late sown condition. Therefore, the varieties which could sustain their yield level under temperature as high as $35.30 \mathrm{C}$ with the least reduction have been considered as thermotolerant varieties. 


\section{Grain yield}

The statistical analysis of the data revealed that sowing time, variety and interaction between $\mathrm{D} X \mathrm{~V}$ significantly affected grain yield per ha (Table 1). Crop sown in timely condition produced the highest (2800.88 $\mathrm{kg} / \mathrm{ha}$ ) grain yield as compared to late sown condition $(2308.63 \mathrm{~kg} / \mathrm{ha})$ reducing the yield to the tune of $25.38 \%$. Considering the varietal effect, GW 433 was found to be superior $(2699.39 \mathrm{~kg} / \mathrm{ha})$ for this character, however, HD 2864 (2697.11 kg/ha), GW 431 (2688.98 kg/ha), RAJ 3765 (2546.32 kg /ha), HI $1571(2533.33 \mathrm{~kg} / \mathrm{ha})$ and HD 3091 $(2519.43 \mathrm{~kg} / \mathrm{ha})$ were at par with it. Minimum $(2405.49 \mathrm{~kg} / \mathrm{ha})$ grain yield was noted in variety HI 1563.

Considering the interaction between $\mathrm{D} X \mathrm{X}$ under timely sown condition (Table 2), HD 2864 gave maximum $(2938.66 \mathrm{~kg} / \mathrm{ha})$ grain yield which was closely followed by GW 431 $(2888.88 \mathrm{~kg} / \mathrm{ha})$ and HD 3091 (2861.11 $\mathrm{kg} / \mathrm{ha}$ ). In late sown condition, maximum $(2588.77 \mathrm{~kg} / \mathrm{ha})$ grain was obtained from GW 433, however, HI $1571(2511.11 \mathrm{~kg} / \mathrm{ha}), \mathrm{GW}$ $431(2489.07 \mathrm{~kg} / \mathrm{ha})$ and HD $2864(2455.55$ $\mathrm{kg} / \mathrm{ha}$ ) were at par with it.

Considering the yield reduction under late sown condition, HI 1571 exhibited the minimum reduction $(1.75 \%)$ followed by GW $433(7.90 \%)$ and GW 431 (13.8\%). Maximum yield reduction was obtained in variety PBW 670 (29.41 \%) under late sown condition.

Lak et al., (11) also obtained lower grain yield with delay in sowing due to shorter duration of growth and development. This was also reflected in the work of Aslani and Mehrvar (12), Abid et al., (13) who confirmed that grain yield was reduced as sowing was delayed. The results were in line with Khokhar et al., (14) reported the maximum grain yield with wheat planted in first fortnight of November and any delayed in wheat planting reduced wheat yield. It might be due to early planted wheat attained maturity in March when mean temperature was around $25^{\circ} \mathrm{C}$ and late planted wheat exposed to higher $\left(32.2^{0} \mathrm{C}\right)$ temperature of April. Refay (15) and Ahmed et al., (16) also observed that remarkable reduction in grain yield associated with late sowing as compared with the early sowing. It was may be due to increased temperature $\left(2-4^{0} \mathrm{C}\right)$ at the time of grain filling period in late sowing condition.

One of the main reasons for reduced yield is the decreased in plant water status due to excessive water loss through rapid transpiration caused by high temperature Kumar et al., (17). Exposure of late sown crop to high temperature during reproductive growth stage also reduces grain filling period and remobilization of photosynthates to developing grains which reduces grain yield Fisher (18). Thus varieties HI 1571, GW 433 and GW 431 could be considered as thermotolerant varieties in view of the least reduction in their grain yield under late sown condition.

\section{Leaf area index (LAI)}

Leaf area index (LAI) represents the ratio of the crop leaf area on the surface which the leaf occupies. Statistical analysis of the data revealed that sowing time, variety and interaction between $\mathrm{D} \mathrm{X} \mathrm{V}$ had significant effect on leaf area index. Higher leaf area index (3.82) was recorded for crop planted under timely sown condition than the delayed sown crop (3.69). Considering the varietal effect, variety HI 1571 was superior for this character showing a value of 3.89 . Variety GW 433 (3.80) was at par with it. The lowest leaf area index was recorded in GW 432 (3.68) and also in HI 1563 (3.68).

Data on interaction effects between D X V for LAI are presented in Table 4.3.1.1. HI 1571 recorded the highest LAI (4.10) followed by 
GW 433 (3.89) when it was sown in timely condition. However, the lowest LAI (3.71) was observed in GW 432 as well as in HI 1563. Higher LAI (3.75) was noticed in GW 431 under late sown condition however, remaining all varieties were at par with it. Lower LAI (3.66) was found in GW 432, RAJ 3765 and also in HI 1563.

The result is strongly supported by the finding of Kabiret al., (19), who examined the effect of sowing time and cultivars on the growth and yield of chickpea under rainfed condition. They reported the higher LAI under timely sown condition as compared to late sown condition. Singh et al., (20)investigated the growth and yield response of wheat cultivars to hyper thermal stress. Eight promising wheat cultivars involving traditional tall and modern semi-tall were grown under normal ambient and hyper thermal $\left(+3.0^{\circ} \mathrm{C}\right)$ conditions. In this study, they also observed reduction in leaf area index in hyper thermal stress as compared to normal ambient condition. Thus, they explained that in response to hyper thermal stress, the leaf area confined to small area to support the required vegetative growth.

Hussain et al., (1997) studied the growth analysis of chickpea sown at different sowing dates and populations. In his study, they observed that the comparatively superior performance of timely sown crop might be due to higher leaf area index.

Almeselmani and Deshmukh (2012) who evaluated the effect of high temperature stress on different growth, physiological and yield parameters in wheat sown under normal, late and very late sowing in order to expose them to different temperature regime. Seeds of eight irrigated wheat genotypes and twelve rainfed genotypes were analysed, also reported the significant reduction in LAI under late planting condition in all genotypes.
In the present study decreased LAI under late sown condition might be due to shading of leaves and competition between plants for light and other resources, especially when wheat crop encountered high temperatures.

Varieties GW 431, HD 3091 and PBW 670 could maintain comparatively higher LAI than the other varieties, when sown late.

\section{Absolute growth rate}

Absolute growth rate determines the dry matter accumulation per unit time in a plant community. The differences among sowing condition (D), varieties (V) and interaction effects of D X V were significant with respect to AGR. Higher (0.134 gday $\left.^{-1}\right)$ AGR achieved in timely sowing as compared to late sowing condition $\left(0.036\right.$ gday $\left.^{-1}\right)$. Considering the varietal effect, GW 433 recorded maximum AGR (0.124 gday $\left.^{-1}\right)$ however, HD 3091 $\left(0.120\right.$ gday $\left.^{-1}\right)$ and RAJ 3765 (0.116 gday $\left.^{-1}\right)$ were statistically at par with GW 433. The minimum AGR (0.054 gday $\left.^{-1}\right)$ was noted in PBW 670.

The highest AGR (0.204 gday $\left.^{-1}\right)$ was observed in HD 3091 under timely sown condition, however, RAJ 3765 (0.165 gday $\left.^{-1}\right)$ was at par with it (Table 4.3.3.1). Under late sown condition, GW 433 recoded significantly higher $\operatorname{AGR}\left(0.070\right.$ gday $\left.^{-1}\right)$, however, RAJ 3765 (0.66 gday $\left.^{-1}\right)$ was at par with it. Minimum AGR (0.011 gday $^{-1}$ ) was noted in HD 2864.

These results are in line with those of Thombare (23), who evaluated fourteen wheat varieties under two dates of sowing, and the decreased absolute growth rate with delayed sowing. In the present study, decreased AGR under late sown condition might be due to the fact that the crop had shortened life duration under late sown condition as compared to the timely sown crop not allowing it sufficient 
time to add dry matter. Thus, the findings that varieties GW 433, RAJ 3765 and HI 1563 could maintain AGR under late sown condition may point out their ability to tolerate heat stress.

\section{Net assimilation rate}

Net assimilation rate (NAR) is an index of production efficiency of the plant. NAR represents dry weight addition per unit leaf photosynthetic area per unit time. Sowing time effect for NAR was significantly higher under timely sown condition $4.52 \mathrm{gm}^{-2} \mathrm{day}^{-1}$ than under late sown condition $1.97 \mathrm{gm}^{-2}$ day $^{-1}$. Thus there was $56.42 \%$ increase in NAR under timely sown condition.

The varieties differed significantly with respect to NAR. Varieties Raj 3765 (4.92 gm ${ }^{2}$ day $^{-1}$ ) secured the first position followed by GW 433 (4.07 $\left.\mathrm{gm}^{-2} \mathrm{day}^{-1}\right)$. The interaction between $\mathrm{D} \mathrm{X}$ V also showed significant differences (Table 4.3.4.1). In timely sown condition, RAJ 3765 exhibited higher (6.56 $\left.\mathrm{gm}^{-2} \mathrm{day}^{-1}\right)$ NAR followed by HI 1563 (5.47 $\mathrm{gm}^{-2}$ day $\left.^{-1}\right)$. RAJ 3765 also retained first position (3.28 $\left.\mathrm{gm}^{-2} \mathrm{day}^{-1}\right)$ under late sown condition however,GW 433 (3.27 $\left.\mathrm{gm}^{-2} \mathrm{day}^{-1}\right)$ was at par with it.GW 431 exhibited minimum NAR.

This finding corroborates the results obtained by Haider (24), who reported that the date of sowing significantly influenced the net assimilation rate. Timely sown crop has a better photosynthetic efficiency as evidenced by high RGR,CGR, LAI and LAD which explain the concomitant increase in NAR. Decrease in leaf area and photosynthesis resulted reduction in NAR under late sown condition as reported by Khabiri and Jafari (25).

Thus, it may be safely concluded varieties RAJ 3765, GW 433 and HI 1563 could be thermo-tolerant varieties since they performed better in term of production efficiency even when the late sown crop faced adverse condition in terms of temperature stress and enforced maturity.

\section{Specific leaf weight}

The specific leaf weight indicates the leaf thickness. The differences between sowing dates with respect to specific leaf weight were statistically non-significant. However, SLW under late sown condition was numerically higher $\left(0.48 \mathrm{gm}^{-2}\right)$. SLW was significantly influenced by varieties. The variety GW 433 was superior for this character showing a value of $\left(0.59 \mathrm{gm}^{-2}\right)$ followed by $\mathrm{GW} 432$ $\left(0.53 \mathrm{gm}^{-2}\right)$. The interaction between $\mathrm{D} \mathrm{X} \mathrm{V}$ was also statistically significant (Table 4.3.5.1). In timely sown condition, GW 433 exhibited maximum $\left(0.61 \mathrm{gm}^{-2}\right)$ SLW, however, GW $432\left(0.57 \mathrm{gm}^{-2}\right)$ and HI 1563 $\left(0.50 \mathrm{gm}^{-2}\right)$ were at par with it. Under late sown condition, GW $433\left(0.56 \mathrm{gm}^{-2}\right)$ retained the first position, however, RAJ 3765 (0.53 $\left.\mathrm{gm}^{-2}\right)$, HI $1571\left(0.50 \mathrm{gm}^{-2}\right), \mathrm{GW} 431(0.50$ $\left.\mathrm{gm}^{-2}\right), \mathrm{GW} 432\left(0.49 \mathrm{gm}^{-2}\right)$ and HD 2864 $\left(0.47 \mathrm{gm}^{-2}\right)$ were at par with it. PBW 670 $\left(0.42 \mathrm{gm}^{-2}\right)$ recorded minimum SLW.

This result is in contrast with that of Khalil et al., (26) who, while evaluating in leaf traits, yield and yield components of fababean in response to planting dates, found the reduction in specific leaf weight under late sown condition due to decrease in leaf area and leaf dry weight. Singh (27) investigated the variation in physiological traits for thermo-tolerance in wheat. In his study, he found that the growth and morphological characters of wheat at anthesis along with SLW registered drastic reduction. To summarize, it could be inferred that SLW was increased in late sown condition whereas variety GW 433 proved to be the best. Numerical increase in SLW under late condition helped plants to withstand higher stress through increase in leaf thickness. 
Thus, varieties GW 433, RAJ 3765, GW 431 and HI 1571 through maintaining the leaf thickness, tried to tolerate heat stress under late sown condition.

\section{Correlation coefficient analysis}

Correlation coefficient revealed that there was significant correlation between grain yield and gluten content $\left(-0.4680^{*}\right)$ but in negative direction. It is quite obvious from the table that grain yield showed very strong positive association with net assimilation rate and absolute growth rate. Leaf area index also had positive correlation with grain yield but were non-significant, whereas, specific leaf weight had negative and non-significant correlation.
These results are supported by Boyadjieva and Andonov (28), who evaluated the selection efficiency of morphological and physiological parameters of wheat. They reported the positive correlation of grain yield with days to heading and physiological maturity. Haider (24), examined the growth analysis in relation to sowing dates in four varieties of wheat and reported that grain yield was positively correlated with growth attributes like LAR, SLW. Sharma et al., (29) examined the correlation and heat susceptibility index analysis for terminal heat tolerance in bread wheat. They also observed high correlation of grain yield with days to anthesis and days to maturity

Table.1 Effect of sowing dates on grain yield and growth parameters of wheat varieties under timely and late sown conditions

\begin{tabular}{|c|c|c|c|c|c|}
\hline Treatment & $\begin{array}{c}\text { Grain Yield } \\
\text { (Kg/ha) }\end{array}$ & $\begin{array}{l}\text { Leaf area } \\
\text { index }\end{array}$ & $\begin{array}{l}\text { Absolute growth } \\
{\text { rate }\left(\text { gday }^{-1}\right)}^{-1}\end{array}$ & $\begin{array}{l}\text { Net assimilation } \\
\operatorname{rate}\left(\mathrm{gm}^{-2} \text { day }^{-1}\right)\end{array}$ & $\begin{array}{r}\text { Specific leaf } \\
\text { weight }\left(\mathrm{g} \mathrm{m}^{-2}\right)\end{array}$ \\
\hline \multicolumn{6}{|c|}{ Sowing Time (D) } \\
\hline Timely $\left(D_{1}\right)$ & 2800.88 & 3.82 & 0.134 & 4.52 & 0.45 \\
\hline Late $\left(\mathbf{D}_{2}\right)$ & 2308.63 & 3.69 & 0.036 & 1.97 & 0.48 \\
\hline S.Em. \pm & 33.39 & 0.02 & 0.002 & 0.08 & 0.0001 \\
\hline C.D. at $5 \%$ & 100.10 & 0.05 & 0.006 & 0.23 & NS \\
\hline \multicolumn{6}{|l|}{ Variety (V) } \\
\hline GW $433\left(V_{1}\right)$ & 2699.39 & 3.80 & 0.124 & 4.07 & 0.59 \\
\hline GW $431\left(V_{2}\right)$ & 2688.98 & 3.78 & 0.065 & 1.96 & 0.45 \\
\hline HI $1571\left(V_{3}\right)$ & 2533.33 & 3.89 & 0.077 & 2.84 & 0.44 \\
\hline GW $432\left(V_{4}\right)$ & 2486.11 & 3.68 & 0.072 & 3.31 & 0.53 \\
\hline RAJ $3765\left(V_{5}\right)$ & 2546.32 & 3.70 & 0.116 & 4.92 & 0.46 \\
\hline HD $2864\left(V_{6}\right)$ & 2697.11 & 3.75 & 0.044 & 2.44 & 0.44 \\
\hline HI $1563\left(V_{7}\right)$ & 2405.49 & 3.68 & 0.093 & 3.93 & 0.47 \\
\hline HD $3091\left(V_{8}\right)$ & 2519.43 & 3.77 & 0.120 & 3.65 & 0.41 \\
\hline PBW $670\left(V_{9}\right)$ & 2416.66 & 3.77 & 0.054 & 2.11 & 0.41 \\
\hline S.Em. \pm & 70.83 & 0.03 & 0.004 & 0.16 & 0.02 \\
\hline C.D. at $5 \%$ & 212.35 & 0.10 & 0.012 & 0.49 & 0.07 \\
\hline \multicolumn{6}{|l|}{ DxV } \\
\hline S.Em. \pm & 100.17 & 0.05 & 0.006 & 0.23 & 0.04 \\
\hline C.D. at $5 \%$ & 300.31 & 0.14 & 0.017 & 0.70 & 0.11 \\
\hline C.V. \% & 6.79 & 2.11 & 11.761 & 12.45 & 13.0393 \\
\hline
\end{tabular}


Table.2 D x V interaction for grain yield and growth parameters of wheat varieties under timely and late sown conditions

\begin{tabular}{|c|c|c|c|c|c|c|c|c|c|c|c|}
\hline \multirow{2}{*}{$\begin{array}{c}\text { Sowing } \\
\text { Time }\end{array}$} & \multicolumn{9}{|c|}{ Variety } & \multirow[t]{2}{*}{ S.E. \pm} & \multirow{2}{*}{$\begin{array}{c}\text { C.D. at } \\
5 \%\end{array}$} \\
\hline & GW 433 & GW 431 & HI 1571 & GW 432 & RAJ 3765 & HD 2864 & HI 1563 & HD 3091 & $\begin{array}{c}\text { PBW } \\
670\end{array}$ & & \\
\hline \multicolumn{12}{|c|}{ Grain Yield (Kg/ha) } \\
\hline Timely & 2810.00 & 2888.88 & 2555.55 & 2777.77 & 2814.86 & 2938.66 & 2727.76 & 2861.11 & 2833.33 & \multirow[b]{2}{*}{100.17} & \multirow[b]{2}{*}{300.31} \\
\hline Late & 2588.77 & 2489.07 & 2511.11 & 2194.44 & 2277.78 & 2455.55 & 2083.22 & 2177.76 & 2000.00 & & \\
\hline \multicolumn{12}{|c|}{ Leaf area index } \\
\hline Timely & 3.89 & 3.81 & 4.10 & 3.71 & 3.74 & 3.81 & 3.71 & 3.81 & 3.80 & \multirow{2}{*}{$0 . .5$} & \multirow{2}{*}{0.14} \\
\hline Late & 3.71 & 3.75 & 3.67 & 3.66 & 3.66 & 3.68 & 3.66 & 3.73 & 3.73 & & \\
\hline \multicolumn{12}{|c|}{ Absolute growth rate $\left(\mathrm{g} \mathrm{day}^{-1}\right)$} \\
\hline Timely & 0.178 & 0.115 & 0.122 & 0.109 & 0.167 & 0.077 & 0.141 & 0.204 & 0.091 & \multirow[b]{2}{*}{0.006} & \multirow[b]{2}{*}{0.017} \\
\hline Late & 0.070 & 0.015 & 0.032 & 0.034 & 0.066 & 0.011 & 0.044 & 0.037 & 0.018 & & \\
\hline \multicolumn{12}{|c|}{ Net assimilation $\operatorname{rate}\left(\mathrm{g} \mathrm{m}^{-2} \mathrm{day}^{-1}\right)$} \\
\hline Timely & 28.73 & 29.13 & 29.20 & 29.20 & 29.53 & 28.50 & 29.03 & 31.60 & 28.83 & \multirow[b]{2}{*}{0.23} & \multirow[b]{2}{*}{0.70} \\
\hline Late & 30.87 & 29.37 & 30.93 & 30.13 & 29.57 & 30.40 & 30.73 & 30.57 & $\begin{array}{r}3 \\
0.57\end{array}$ & & \\
\hline \multicolumn{12}{|c|}{ Specific leaf weight $\left(\mathrm{g} \mathrm{m}^{-2}\right)$} \\
\hline $\begin{array}{c}\text { Timely } \\
\left(D_{1}\right)\end{array}$ & 0.61 & 0.40 & 0.39 & 0.57 & 0.40 & 0.41 & 0.50 & 0.39 & 0.39 & \multirow[t]{2}{*}{0.04} & \multirow[t]{2}{*}{0.11} \\
\hline Late $\left(\mathrm{D}_{2}\right)$ & 0.56 & 0.50 & 0.50 & 0.49 & 0.53 & 0.47 & 0.43 & 0.44 & 0.42 & & \\
\hline
\end{tabular}


Table.3 Correlation coefficient (' $r$ ' values) between grain yield and biochemical parameters of wheat varieties under timely and late sown conditions

\begin{tabular}{|c|c|c|}
\hline Sr. No. & Parameters & $\begin{array}{c}\text { Correlation coefficient ('r' value) } \\
\text { with grain yield }\end{array}$ \\
\hline $\mathbf{1}$ & Leaf area index & 0.3824 \\
\hline $\mathbf{2}$ & Absolute growth rate & $0.7020^{* *}$ \\
\hline $\mathbf{3}$ & Net assimilation rate & $0.6501^{* *}$ \\
\hline $\mathbf{4}$ & Specific leaf weight & -0.0314 \\
\hline
\end{tabular}

In conclusion, the study showed that there was reduction in grain yield of wheat under late sown condition compared to timely sown condition. Considering grain yield performance, HD 2864, GW 431 and HD 3091 showed an increase in grain yield under timely sown condition, while GW 431, GW 433 and HI 1571 fared better under late sown condition with respect to grain yield. Considering yield reduction under late sown condition, HI 1571 (1.73\% reduction), GW 433 (7.90\% reduction) and GW $431(13.8 \%$ reduction) showed minimum yield reduction compared to other varieties. Growth parameters were significantly higher in timely sown condition as compared to late sown condition. However, specific leaf weight was numerically higher in late sown condition. Under late sown condition, variety GW 433 recorded higher AGR and SLW while GW 431 had maximum LAI. RAJ 3765 recorded maximum NAR under late sown condition.

Correlation coefficient, grain yield showed very strong significant positive association with net assimilation rate and absolute growth rate. leaf area index also had positive correlation with grain yield but were nonsignificant. Specific leaf weight had negative and non-significant correlation. Considering grain yield performance, HD 2864, GW 431 and HD 3091 showed increased grain yield under timely sown condition, while GW 431, GW 433 and HI 1571 fared better under late sown condition. Varieties HI 1571 had the least reduction in grain yield $(1.73 \%)$, followed by GW 433 (7.90\%) and GW 431 $(13.8 \%)$. Thus, they could be labelled as thermo-tolerant varieties and could be recommended for late sown conditions.

\section{References}

Abid, M., S. Ali, L.K. Qi, R. Zahoor, Z. Tian, D. Jiang, J. L. Snider and T Dai (2018). Physiological and biochemical changes during drought and recovery periods at tillering and joining stages in wheat (Triticum aesticum L.), Sci.Rep-UK., 8(1):4615.

Ahmed, M., M. A. Aslam, F. Hassan, R. Hayat and S. Ahmad (2019). Biochemical, physiological and agronomic response of wheat to changing climate of rainfed Pakistan. Pak. J. Bot., 51(2): 1-17.

Almeselmani, M. and Deshmukh, P. S. (2012). Effect of high temperature stress on physiological and yield parameters of some wheat genotypes recommended for irrigation and rainfed condition. Jordan J. Agri. Sci., 8(1): 66-78.

Aslani F. and M. R. Mehrvar (2012). Responses of wheat genotypes as affected by different sowing dates. Asian J. Agri. Boil., 1(4):89-93.

Bogard, M., Jourdan, M., Allard, V., Martre, P., Perretant, M. R., Ravel, C., Heumez, E., Orford, S., Snape, J., Griffiths, S., Gaju, O., Faulkes, J. and Gouis, J. Le. (2011). Anthesis date 
mainly explained correlation between post-anthesis leaf senescence, grain yield and grain protein concentration in a winter wheat population segregating for flowering time QTLs. J.Exp. Bot., 62: 3621-3636.

Boyadjieva, D. and Andonov, B. (2010). Selection efficiency of morphological and physiological parameters of $T$. aestivum in dry climatic conditions. Buigarian J. Agril. Sci., 16(5): 539546.

Fisher R. A. (2007). Understanding the physiological basis of yield potential in wheat J. Agric. Sci., 145: 99-113.

Haider, S. A. (2007). Growth analysis in relation to sowing dates in four varieties of wheat a functional approach. J. Life Earth Sci., 2(2): 1725.

Hussain, A., Nawaz, M., Azam, M. and Kamram, M. (1997). Growth analysis of chickpea (Cicer arietinum L.) sown at different sowing dates and populations. J. Agric. Res., 35(4): 227 236.

Jiang, D., Yue, H., B. Wollenweber, W. Tan, W. Mu \& Y. Bo (2009). Effect of post- anthesis drought and waterlogging on accumulation of high molecular weight glutenin subunits and glutenin macropolymers content in wheat grain. Journal of Agronomy and Crop Science, 195: 89-97.

Kabir, A. H. M. F., Bari, M. N., Karim MD. A., Khaliq Q. A. and Ahmed L. U. (2009). Effect of sowing time and cyltivals on the growth aand yield of chickpea under rainfed condition. Bangladesh J. Agril. Res. 34(2): 335342.

Khabiri, E. and Jafari, M. 2012. The effect of different light levels on the growth of wheat gascogne. Int. Reas. J. Appl. Basic Sci., 3(12): 2358-2363.

Khalil, N. A. W. Murshidy, M.O. Khaity and
R. Elbadawy (2011). Variation in leaf traits, yield and yield components of faba bean in response to planting dates and densities. Egypt Acad. J. Biolog. Sci., 2(1): 35-43.

Khokhar Z., I. Hussain, B. khokhar and M. Sohail (2010). Effect of planting date on yield of wheat genotypes in sindh. Pak. J. Agric. Res., 23(3-4): 103-107.

Kumar, S., Alam, P. and Ali, N. (2013). Response of wheat (Triticum aestivum L. emed. Fori and Paol.) varieties to sowing dates. J. Res., 25(1): 56-59.

Labuschagne, M. T., O. Elago and E. Koen (2009). The influence of temperature extremes on quality and starch characteristics in bread, biscuit and durum wheat. Cereal Chemistry, 86: 61-66.

Lak M., A. Farnia and M. Shaban (2013). Effect of different sowing dates on yield components of wheat (Triticum aestivum L.) cultivars in lorestan province, Iran. Adv. Agri. Boil., 1(4): 89-93.

Larson, H. \& A. C. Eliasson (1997). Influence of the starch granule surface on the rheological behavior of wheat flour dough. Journal of Texture Studies, 28: 487-501.

Oak, M. D., R. M. Patil, D. N. Bankar, J. H. Bhagwan, A. L. Bipinraj, S. A. Tamhankar, B. K. Honrao \& S. C. Misra (2011). Performance of durum wheat lines for quality and rust resistance. J. Wheat Res., 3(1): 71-72.

Panse, V.G. and P. V. Sukhatme (1985). Statistical Methods for Agricultural Workers. I.C.A.R. Pub., New Delhi.

Rahman, M. A., Chikushi, J., Yoshida, S. and Karim, A. J. M. S. (2009). Growth and yield components of wheat genotypes exposed to high temperature stress under control environment. Bangladesh J. Agril. Res. 34(3): 361372. 
Refay Y. A. (2011). Yield and yield component parameters of bread wheat genotypes as affected by sowing dates. Middle-East J. Sci. Res., 7(4): 484489.

Saeedipour, S. (2011). Effect of drought at the post-anthesis stage on remobilization of carbon reserves in two wheat cultivars differing in senescence properties. International J. Plant Physiol, Biochem., 3: 15-24.

Sharma, A., Rawat, R. S., Verma, J. S. and Jaiswal, J. P. 2013. Correlation and heat susceptibility index analysis for terminal heat tolerance in bread wheat. J. Central European Agri.14(2): 535544.

Singh, S. (2009). Variation in physiological traits for thermo- tolerance in wheat. Indian J. Plant Physil. 14(4): 122-127.
Singh, S., Jain, M. C. and Singh J. P. (2001). Growth and yield response of wheat cultivars to hyper thermal stress. 6(4): 395-402.

Srivastava, N., Singh, D., Shukla, A., Guru, S. K., Singh, M. and Rana, D. S. (2012). Effect of high temperature stress at post anthesis stage on photo system II, senescence, yield and yield attributes of wheat genotypes. Indian J. Plant Physil., 17(2): 158-165.

Thombare, A. K. (2010). Heat tolerance studies in wheat (Triticum aestivum and durum L.) genotypes M.Sc. thesis, M. A. U., Maharashtra, India.

Wardlaw, I. F. (1994). The response of wheat to high temperature following anthesis. I. The rate and duration of kernel filling. Australian Journal of Plant Physiology, 21: 731-739.

\section{How to cite this article:}

Shital Bangar, Chetana Mandavia, Diksha Tajane and Mandavia, M. K. 2020. Effect of Sowing Dates on Yield and Growth Parameters on Different Wheat (Triticum aestivum L.) Varieties. Int.J.Curr.Microbiol.App.Sci. 9(03): 2139-2148. doi: https://doi.org/10.20546/ijcmas.2020.903.244 